\title{
Characterization of post-surgical critical patients with infections associated with healthcare after prolonged perfusion of remifentanil
}

Dosé Luis Bonilla García Manuel Cortiñas Sáenz ${ }^{2}$ Esperanza del Pozo Gavilán ${ }^{3}$

\author{
1. FEA Anestesiología y Reanimación. Complejo Hospitalario Universitario de Huelva, Huelva, Huelva, Spain \\ 2. FEA Anestesiología y Reanimación. Hospital Torrecárdenas de Almería, Almería, Almería, Spain
} 3. Departamento de Farmacología e Instituto de Neurociencias. Facultad de Medicina, Universidad de Granada, Granada, Spain

http://dx.doi.org/10.1590/1806-9282.64.08.736

\section{SUMMARY}

INTRODUCTION: Healthcare associated infections (HAI) are the most frequent complication of hospitalized patients. The aim of this study was to describe the clinical and epidemiological characteristics of critically ill post-surgical patients with a diagnosis of healthcare associated infections, after a pattern of sedoanalgesia of at least 4 days.

METHODS: All patients over 18 years of age with a unit admission of more than 4 days were consecutively selected. The study population was the one affected by surgical pathology where sedation was based as analgesic the opioid remifentanil for at least 96 hours in continuous perfusion. Patients who died during admission to the unit and those with combined analgesia (peripheral or neuroaxial blocks) were excluded. Data analysis was performed using the statistical package Stata version 7.0.

RESULTS: The patients admitted to the Post-Surgical Critical Care Unit (PCU) during study were 1789 and the population eligible was comprised of 102 patients. 56.86\% of patients suffered IACS. The most frequent IACS was pneumonia associated with mechanical ventilation (30.96 per 1000 days of mechanical ventilation), Pseudomonas aeruginosa being the most frequently isolated germ. The germs with the greatest involvement in multiple drug resistance (MDROs) were enterobacteria, mainly Klebsiella pneumoniae resistant to extended-spectrum beta-lactamases (ESBL).

CONCLUSIONS: Pneumonia associated with mechanical ventilation is the most prevalent HAl and Pseudomonas aeruginosa is the main etiological agent. The groups of antibiotics most frequently used were cephalosporin and aminoglycosides. It is necessary to implement the prevention strategies of the different HAl, since most of them are avoidable.

KEYWORDS: Analgesics, opioid. Cross infection. Immunosuppression. Critical care. Piperidines/administration \& dosage.

\section{INTRODUCTION}

Healthcare Associated Infections (HAI), formerly known as nosocomial or in-hospital, are those infections that did not manifest nor were incubated at the time of admission and the patient acquired it during treatment for any medical or surgical condition. It is necessary that they occur after 48 hours of hospitalization ${ }^{1}$.
HAI are the most frequent complication of hospitalized patients. In Spain, according to the data provided by the EPINE Project ${ }^{2}$, prevalence of HAI is estimated at around $7.5-8 \%$ in the last 4 years, with a recovery in 2015 compared to the previous years. This prevalence increases to $23.52 \%$ in critically ill patients, with intensive care units being the most prevalent areas. 
The development of infections is associated with multiple causes, including, but not limited to, the use of medical devices, post-surgical complications, transmission between patients and healthcare personnel, and the outcome of frequent antibiotic treatment. On the other hand, we must also consider different host conditions that predispose to HAI acquisition, among them, immunosuppression, either by pre-existing or drug-induced comorbidities ${ }^{3}$.

Among the drugs administered to the seriously ill patient, different combinations of pain killers and hypnotics are essential to ensure their comfort, care and safety ${ }^{4}$. However, inappropriate use of these drugs may increase morbidity and mortality, mechanical ventilation time, and length of hospital stay.

Sedoanalgesia alters immune function, but its real clinical importance is unknown. Several animal and human studies have demonstrated the immunosuppressive effects of opioids, ${ }^{5}$ consequently associating the administration of opioids with increased susceptibility to certain bacterial and viral infections ${ }^{6}$. Morphine is associated with decreased lymphoproliferative processes, Natural killer (NK) lymphocyte activity and the production of interferon- $\gamma$ and IL- $2^{7}$.

Several animal studies suggest that the withdrawal of opioids induces a state of immunosuppression that would increase the risk of infection ${ }^{8}$ and therefore, the modification of immunomodulation by certain drugs may be responsible for part of the HAI complications in critical medicine. In this sense, the study by Nseir et al. ${ }^{9}$ shows that the discontinuation of the remifentanil opioid in perfusion in critical post-surgical patients represents an independent risk factor for the development of HAI.

The objective of this study is to describe the clinical, demographic and epidemiological characteristics of critical post-surgical patients diagnosed with healthcare-associated infection with admission to the Post-Surgical Resuscitation Unit (URP) for two years, whose sedation was based on association of a hypnotic with remifentanil as a pain killer in continuous perfusion for at least 96 hours, based on the hypothesis, with increase of HAI on withdrawal of the opioid remifentanil.

\section{MATERIAL AND METHODS}

Following the approval of the Hospital Ethics Committee, a prospective and observational study of a historical court was conducted in a Post-Surgi- cal Resuscitation Unit with 6 beds during the years 2010-2012.

All patients aged over 18 years with admission to the unit over 4 days were consecutively selected. The study population was the one affected by surgical pathology from any source in which sedation was based on any hypnotic and as pain killer, the opioid remifentanil for at least 96 hours in continuous infusion. Patients who died during admission to the unit and patients with combined analgesia (peripheral or neuroaxial block) were excluded.

Doses of midazolam, propofol, and remifentanil are described in the unit sedoanalgesia protocol, following the Guidelines of the Society of Critical Care Medicine $^{10}$. Initially, remifentanil was administered at a dose of 0.05-0.20 $\mu \mathrm{g} / \mathrm{kg} / \mathrm{min}$. If the ideal Ramsay level was not achieved, propofol was associated at $0.5-4 \mathrm{mg} / \mathrm{kg} / \mathrm{h}$, if the patient remained hemodynamically stable, or otherwise, midazolam at 0.05-0.20 $\mathrm{mg} / \mathrm{kg} / \mathrm{h}$. Ketamine hydrochloride was administered if the desired goal was not achieved. The deprivation syndrome is treated within the strategy of sequential sedation.

The main variable of our study was the number of infections associated with healthcare acquired in the URP during the days of hospitalization. We also considered incidence density, defined as the number of infections acquired in the unit per 1000 days of hospitalization.

The cut-off point between early and late HAI was established as 6 days before and after remifentanil cessation.

There is a HAI surveillance system with systematic and routine detection of multiresistant germs. Only the infections confirmed by the Microbiology Service were considered for this study. The different HAI were defined according to the definitions of the Centres for Disease Control and Prevention (CDC) $)^{11}$.

Other variables collected were: age, gender, APACHE II rating (Acute Physiology and Chronic Health Evaluation II), ASA index (American Society of Anaesthesiologists), McCabe score, number and type of comorbidity, cause of hospitalization, number of surgical reinterventions, previous treatment with antibiotics, stay in the Ramsay URP, ratio of use of central and arterial venous catheters, closed system urinary catheters and mechanical ventilation, number of reintubations, tracheostomy, duration and type of antimicrobial agent, dose of remifentan- 
il, midazolam and propofol, use of neuromuscular blocking drugs and mortality.

For the empirical treatment of infectious processes the recommendations were used based on the therapeutic guidelines of the Sociedade Espanhola de Anestesiologia y Reanimación (Spanish Society of Anaesthesiology and Reanimation) adjusted for the local epidemiology of bacterial resistance of our critical unit ${ }^{12}$.

In patients with sepsis on admission, vigorous resuscitation measures with fluid and instauration of hemodynamic support measures by vasopressors were initiated if there was hypotension or lactate $>4 \mathrm{mmol} / \mathrm{L}$, low-dose corticosteroids in patients with septic shock, mechanical invasive ventilation of pulmonary protection, glycaemia control between $150-180 \mathrm{mg} / \mathrm{dl}$, assessment of need for surgical intervention or percutaneous drainage, culture and beginning of empirical antimicrobial treatment based on Surviving Sepsis Campaign guidelines ${ }^{13}$.

Data analysis was performed using the statistical package Stata version 7.0. The results are presented as number of percentages for the categorical variables and mean with their standard deviation for the quantitative variables.

\section{RESULTS}

The number of patients admitted to the URP during the study period was 1,072. After applying the inclusion and exclusion criteria, the eligible population consisted of 102 patients whose analgesic protocol was carried out by intravenous infusion of remifentanil for at least 96 hours. $56.86 \%$ of patients had HAI.

The main demographic data, associated comorbidity conditions, rate of use of medical devices and drugs applied in the sedoanalgesia of the study cohort that developed HAI are presented in Tables 1, 2 and 3. The age was $68.37 \pm 10.79$ years old. The mean length of stay in the URP was $19.87 \pm 14.29$ days, with total hospital stay of $40.39 \pm 27.53$ days. Mean APACHE II on admission was $18.27 \pm 8.15$. 53.44\% (31 cases) of admissions to the unit that were emergencies.

The mean infusion rate of remifentanil was 11.4 ug kg-1 h-1. 64\% simultaneously received sedation with midazolam, $31 \%$ with propofol, and the rest did not receive sedative drugs, only remifentanil. The remifentanil infusion was during the study period of $14.93 \pm 11.35$ days. The mean medical remifentanil infusion per day of study and in relation to the hypnotic administered is shown in figure 1 .

Figure 2 shows the number of HAI in temporal relation to the administration and removal of intravenous remifentanil. We did not observe statistically significant differences in its incidence in relation to discontinuation of remifentanil, using the Mann-Whitney U test $(p=0.19)$.

The most frequent HAI was pneumonia associated with mechanical ventilation (30.96 per 1000 days of mechanical ventilation), with Pseudomonas aeruginosa being the most frequently isolated germ. The incidence density of primary and/or secondary bacteraemia and urinary tract infection was 23.87 and 9.67 per 1000 days of risk factor, respectively. The germs most involved in multidrug resistance (MDROs) were enterobacteria mainly Klebsiella pneumoniae resistant to extended spectrum betalactamases (ESBL).

The most commonly used antibiotic groups were cephalosporin and aminoglycosides (figure 3). Fungicides were used in 15 cases.

TABLE 1. CHARACTERISTICS OF THE STUDY POPULATION ADMITTED TO THE URP

\begin{tabular}{|c|c|}
\hline VARIABLES. & IN. $(n=58)$ \\
\hline Age & $68.37 \pm 10.79$ \\
\hline Gender (Male) & $26(44)$ \\
\hline $\mathrm{ASA}>2$ & $44(75)$ \\
\hline $\begin{array}{l}\text { Score McCabe. } \\
\text { Good prognostic } \\
\text { Poor prognostic } \\
\text { Fatal prognostic } \\
\text { Death expectations }\end{array}$ & $\begin{array}{l}13 \\
15 \\
20 \\
10\end{array}$ \\
\hline $\begin{array}{l}\text { Basal Comorbidity } \\
\text { Hemodynamic } \\
\text { Respiratory } \\
\text { Renal } \\
\text { Hepatic } \\
\text { Neoplasia } \\
\text { Immunosuppression } \\
\text { Diabetes mellitus }\end{array}$ & $\begin{array}{l}31(53) \\
27(46) \\
16(27) \\
10(17) \\
43(74) \\
32(55) \\
25(43)\end{array}$ \\
\hline $\begin{array}{l}\text { Number of Comorbidities } \\
\leq 2 \\
>2\end{array}$ & $\begin{array}{l}22(37) \\
36(62)\end{array}$ \\
\hline APACHE II & $18.27 \pm 8,15$ \\
\hline Days of admission to URP & $19.87 \pm 14.29$ \\
\hline $\begin{array}{l}\text { Days of admission to hospital } \\
\text { Pre-URP } \\
\text { Post-URP } \\
\text { Global }\end{array}$ & $\begin{array}{l}4.25 \pm 4.10 \\
16.10 \pm 21.76 \\
40.39 \pm 27.53\end{array}$ \\
\hline $\begin{array}{l}\text { Mortality } \\
\text { UCC } \\
\text { Post-URP }\end{array}$ & $\begin{array}{l}18(31) \\
12(20)\end{array}$ \\
\hline $\begin{array}{l}\text { Type of Surgery } \\
\text { Scheduled } \\
\text { Emergency }\end{array}$ & $\begin{array}{l}27(46) \\
31(53)\end{array}$ \\
\hline Reintubation & $2(37)$ \\
\hline
\end{tabular}




\section{DISCUSSION}

HAI are the most frequent complication of hospitalized patients. According to data provided by the National Survey of Nosocomial Infection Surveillance in Intensive Care Services (ENVIN) of 2015 ${ }^{14}$, in postoperative patients, the most frequent $\mathrm{HAI}$ are related to ventilator-associated pneumonia (VAP), catheter-related urinary tract infection (UTI) and bacteraemia of unknown origin associated with the catheter. This data is consistent with those of our cohort, since ventilator-associated pneumonia was the most frequent cause, with a DI of 30.96 per 1000 days of mechanical ventilation followed by primary and/or secondary bacteraemia, and urinary tract infection with ID 23.87 and 9.67 per 1,000 days of risk factor, respectively.

The main microbiological causes of the different HAI have not undergone major changes in recent years. In relation to our cohort, Pseudomonas aeruginosa is the most frequently isolated in VAP, E. coli in urinary infections, and Staphylococcus epidermidis in bacteraemia, these results being comparable to those presented in several epidemiological studies on HAI in critical patients ${ }^{15}$.

The fact that Pseudomonas aeruginosa is the most frequent pathogen associated with VAP could be justified because this microorganism is related to late VAPs. This circumstance in our study is favoured by the prolonged duration of mechanical ventilation in our patients.

A growing concern in the intensive units is the appearance of multidrug resistant germs, which complicate both the prognosis and the management and evolution of patients, which increases the consumption of resources in the units ${ }^{16}$. In our case, the germs most involved in multidrug resistance (MDROs) were enterobacteria, especially Klebsiella pneumoniae resistant to beta-lactamases (ESBL), which showed, however, a good sensitivity for carbapenems. The low incidence of methicillin-resistant Staphylococcus aureus (MRSA) and the absence of Clostridium difficile carriers are noteworthy. These organisms are identified in national studies as multidrug resistant pathogens ${ }^{14}$.

The causes of these strains of Vancomycin-Resistant Enterococcus (VRE) may be multifactorial. Among these factors are the progressive increase of elderly patients with higher comorbidity, the current economic crisis leading to increased workloads for healthcare professionals and it is associated with a
FIGURE 1. AVERAGE INFUSION OF REMIFENTANIL PER STUDY DAYS IN RELATION TO THE HYPNOTIC USED.

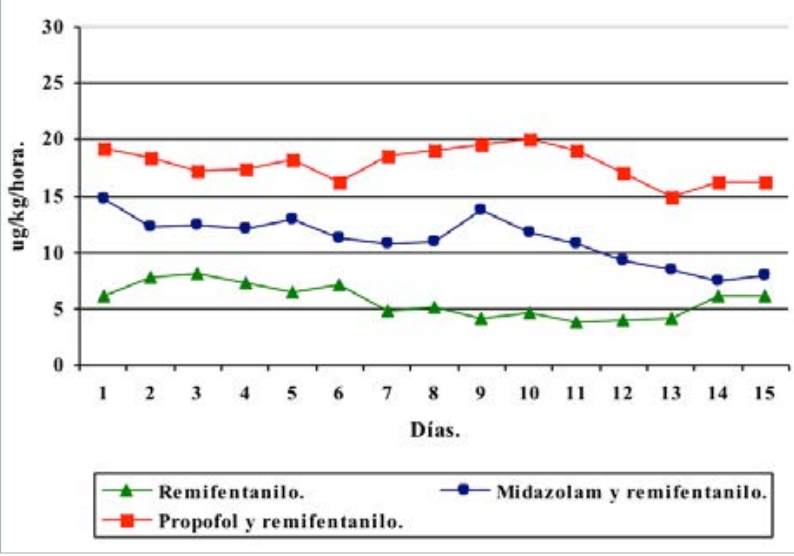

FIGURE 2. TIME RELATION BETWEEN HEALTHCAREASSOCIATED INFECTIONS (HAI) AND INTRAVENOUS REMIFENTANIL ANALGESIA IN A POST-ANESTHESIA CARE UNIT

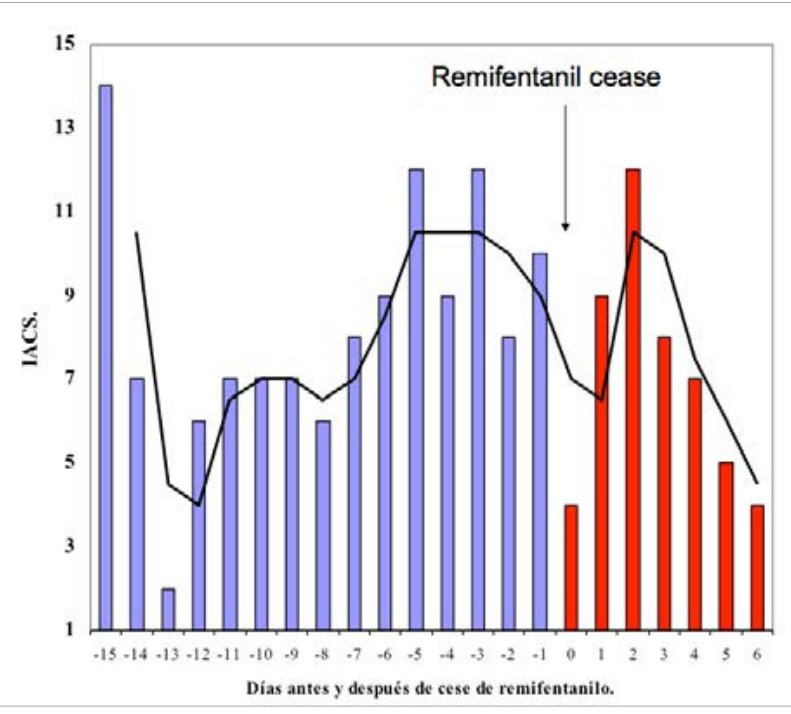

FIGURE 3. ANTIMICROBIAL USED IN URP

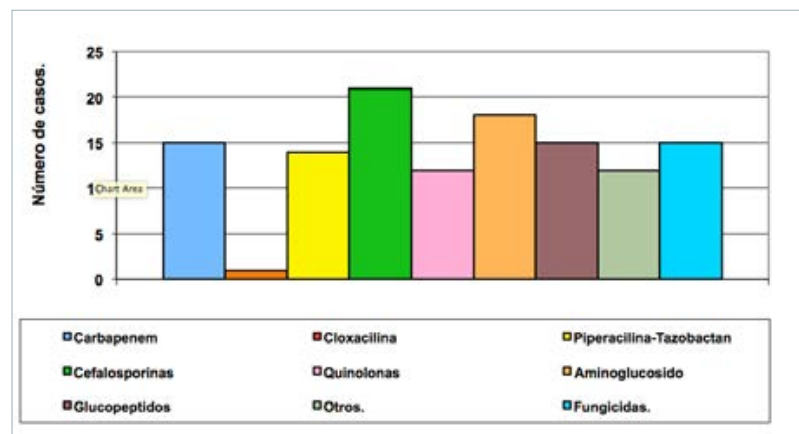

higher risk of infection by MRSA and ERV ${ }^{17}$, or an incorrect antibiotic policy.

In our cohort, antibiotic therapy was adjusted according to SEDAR recommendations, adjusted to our local ecology. The use of antimicrobials in an early 
TABLE 2. USE OF MEDICAL DEVICES BY THE STUDY POPULATION ADMITTED TO THE URP AND TREATED WITH REMIFENTANIL FOR AT LEAST 96 HOURS.

\begin{tabular}{l|l} 
VARIABLES & IN $(n=58)$ \\
\hline CVC & $57(98)$ \\
\hline Days of CVC & $22.62 \pm 16.68$ \\
\hline VMI & $58(100)$ \\
\hline Days of VMI & $13.20 \pm 11.04$ \\
\hline Tracheostomy & 22 \\
\hline Days of Tracheostomy & $10.81 \pm 4.66$ \\
\hline SU & $58(100)$ \\
\hline Days of SU & $23.56 \pm 19.23$ \\
\hline
\end{tabular}

TABLE 3. DRUGS USED IN THE COHORT SEDOANALGESIA

\begin{tabular}{l|l} 
VARIABLES & IN $(\mathbf{n}=58)$ \\
\hline Remifentanil & $3(5)$ \\
\hline Days of Remifentanil & $14.93 \pm 11.35$ \\
\hline Midazolam and Remifentanil & $37(64)$ \\
\hline Days of Midazolam. & $15.21 \pm 13.44$ \\
\hline Propofol and Remifentanil & $18(31)$ \\
\hline Days of Propofol & $8.16 \pm 2.70$ \\
\hline
\end{tabular}

and adequate manner has been shown to reduce the morbidity and mortality of critically ill patients. The employees of our series are in accordance with what has been published in the literature ${ }^{18}$.

In our study we observed that the factors that may have contributed to the emergence of infections by multidrug resistant microorganisms are the advanced age of our cohort as well as the high comorbidity. In our area there is a bacterial resistance surveillance system, but it is probably necessary to introduce and/or potentiate other strategies, such as the molecular typing of isolates, intensification of hygiene measures control, regrouping or cohorting of patients, rotation and restriction in the use of antibiotics, and a rigorous follow-up of patients infected and/or colonized by resistant germs ${ }^{19}$.

Another element to be considered in our study as a factor favouring HAI is the use of prolonged sedoanalgesia based on the use of remifentanil, associated or not with propofol or midazolam hypnotics, to achieve an optimal level of sedation. The transcendence of prolonged use in sedation of critically ill patients may be relevant but there are no clinical studies demonstrating that the specific use of any analgesic or hypnotic drug has an impact on patient survival. Several animal studies suggest that withdrawal of opioids after a variable time of administration induces a state of immunosuppression that would increase the risk of infection ${ }^{8,20}$. In this sense, the effect of certain drugs on immunomodulation could increase the risk of acquiring infections associated with healthcare in intensive units.

Sedation in our work was performed using the midazolam or propofol hypnotics according to the protocol attached. In patients with greater severity, sedoanalgesia was based on the midazolam-remifentanil binomial. Although some studies ${ }^{21}$ have suggested the importance of choosing this in immunocompromised patients with a high risk of infection, we have not found that the applied hypnotic correlates with an increase in HAI when adjusted for severity, medical device utilization ratio and hospital stay.

On the other hand, our study shows that the acute use and the interruption of opioid remifentanil is an independent risk factor for nosocomial infection, unlike the results presented by the Nseir et al. ${ }^{9}$ group. This study showed, after a logistic regression analysis, that there is a high incidence of nosocomial infections during the 4 days after the cessation of analgesia based on opioid remifentanil. In our study, it was observed that patients belonging to the HAI group require more days of sedoanalgesia with remifentanil, with longer exposure to extrinsic factors of infection, such as mechanical ventilation, central venous catheters and urinary catheter exposing them to a higher HAI risk. These data could explain the differences of our results with those obtained in the work of Nseir et al. ${ }^{9}$. Our findings are consistent with the study by Cronin et al..$^{22}$, which shows that infusion of fentanyl has no effect on cellular immune function in healthy volunteers.

For preventing these infections, the implementation of strategies to prevent the different HAI is necessary, since it is possible to prevent most of them and therefore, to put all the resources at our disposal to avoid them. Thus, it is possible to implement both measures common to different HAI and specific ones, depending on the area that presents the greatest needs (training, reduction of risk factors, and adherence to clinical guidelines for the prevention of infection) ${ }^{23}$.

The study has a number of limitations. First, the sample size is limited and extracted from a single intensive unit. Second, the bias of hypnotic choice depending on the hemodynamic instability of the 
subject. Third, the existence of possible periods of infrasedation or oversedation, with the possible immunological and infectious repercussions that could derive from those, which were not tabulated in this study.

In conclusion, $\mathrm{HAI}$ are the most frequent complication of hospitalized patients. VAP is the most prevalent nosocomial infection and Pseudomonas aeruginosa is the most frequently isolated germ. The germs most involved in multidrug resistance (MDROs) are mainly enterobacteria, mainly Klebsiella pneumoniae resistant to extended spectrum beta-lactamases (ESBL). It is necessary to implement prevention strategies for the different HAI, since most of them can be avoided. The statement that remifentanil discontinuation is associated with a high incidence of HAI was not verified in our study.

Given the importance of the topic and areas of uncertainty, it could be of interest to carry out multicentre, controlled, and larger series studies to elucidate all factors related to HAI in critically ill postoperative patients, as it influences their prior immunological status, among others.

\section{ACKNOWLEDGMENTS}

The results of this publication are part of the José Luis Bonilla García Doctoral Thesis, entitled "Relationship between infection rate associated with healthcare in a Post-surgical Critical Unit and suspension of treatment with remifentanil", attached to the Program of Doctorate in "Clinical Medicine and Public Health" from the University of Granada. Thanks to the Andalusian Public Foundation for the Oriental Andalusian Biosanitary Research - Alejandro Otero de Almería for his invaluable help in the study and statistical analysis.

\section{CONFLICTS OF INTEREST}

The authors declare that there is no conflict of interest.

\section{RESUMO}

INTRODUCCIÓN: Las infecciones asociadas a cuidados de salud (IACS) constituyen la complicación más frecuente de los pacientes hospitalizados. El objetivo de este estudio es describir las características clínicas y epidemiológicas de los pacientes críticos postquirúrgicos con diagnóstico de infección asociada a cuidados de salud, tras una pauta de sedoanalegia de al menos 4 días.

MÉTODOS: Se seleccionaron de manera consecutiva todos los pacientes mayores de 18 años con un ingreso en la Unidad de Reanimación Postquirúrgica (URP) superior a 4 días. La población de estudio fue aquella afectada por patología quirúrgica de cualquier origen donde la sedación se basó en cualquier hipnótico y como analgésico el opioide remifentanilo durante al menos 96 horas en perfusión continua. Se excluyeron los pacientes que fallecieron durante su ingreso en la unidad y aquellos pacientes con analgesia combinada (bloqueos periféricos o neuroaxiales). El análisis de los datos se realizó con paquete estadístico Stata versión 7.0.

RESULTADOS: El número de pacientes que ingresaron en la URP durante el periodo de estudio fueron de 1789. Tras aplicar los criterios de inclusión y exclusión, la población elegible quedó constituida por 102 pacientes. Un 56,86\% de pacientes padecieron IACS. La IACS más frecuente fue la neumonía asociada a ventilación mecánica (30,96 por 1000 días de ventilación mecánica) siendo Pseudomona aeruginosa el germen más frecuentemente aislado. Los gérmenes con mayor implicación en las multirresistencias (MDROs) fueron las enterobacterias, principalmente Klebsiella pneumoniae resistente a betalactamasas de espectro extendido (BLEE).

CONCLUSIONES: La neumonía asociada a ventilación mecánica es la IACS más prevalente y Pseudomona aeruginosa es el principal agente etiológico. Los grupos de antibióticos más frecuentemente empleados fueron cefalosporinas y aminoglucósidos. Es necesario implementar las estrategias de prevención de las distintas IACS, ya que la mayoría de ellas son evitables.

PALABRAS CLAVE: Analgésicos opioides. Infección hospitalaria. Inmunosupresión. Cuidados críticos. Piperidinas/administración \& dosificación.

\section{REFERENCES}

1. $\mathrm{CDC} / \mathrm{NHSN}$ Identifying healthcare-associated infections (HAI) for NHSN Surveillance. (Accessed Sept 5, 2016) Available from: http://www.cdc.gov/ nhsn/PDFs/pscManual/2PSC_IdentifyingHAls_NHSNcurrent.pdf

2. Sociedad Española de Medicina Preventiva, Salud Pública e Higiene, European Centre for Disease Prevention and Control. Estudio EPINE-EPPS 2015. Informe Global de España (resumen provisional). (Accessed Sept 5, 2016). Available from: http://hws.vhebron.net/epine/Descargas/ EPINE\%202015\%20INFORME\%20GLOBAL\%2ODE\%20ESPA\%C3\%91A\%2ORESUMEN.pdf

3. Pujol M, Limón E. General epidemiology of nosocomial infections. Surveillance systems and programs. Enferm Infec Microbiol Clin. 2013;31(2):108-13.

4. Chamorro C, Romera MA, Silva JA. Importancia de la sedoanalgesia en los pacientes en ventilación mecánica. Med Intensiva 2003;1(Suppl):2-4

5. Eisenstein TK, Hilburger ME. Opioid modulation of immune responses: effects on phagocyte and lymphoid cell populations. J Neuroimmunol. 1998;83(1-2):36-44.

6. Risdahl JM, Khanna KV, Peterson PK, Molitor TW. Opiates and infections. J Neuroimmunol. 1998;83(1-2):4-18.

7. Garcia JBS, Cardoso MGM, Dos-Santos MC. Los opioides y el sistema inmunológico: relevancia clínica: Rev Bras Anestesiol. 2012;62(5):1-6.

8. Feng P, Wilson QM, Meissler JJ Jr, Adler MW, Einstein TK. Increased sensitivity to Salmonella enterica serovar Typhimurium infection in mice undergoing withdrawal from morphine is associated with suppression of interleukin-12. Infect Immun. 2005;73(12):7953-9. 
9. Nseir S, Hoel J, Grailles G, Soury-Lavergne A, Di Pompeo C, Mathieu D, et al. Remifentanil discontinuation and subsequent intensive care unit-acquired infection: a cohort study. Crit Care. 2009;13(2):R60.

10. Jacobi J, Fraser GL, Coursin DB, Riker RR, Fontaine D, Wittbrodt ET, et al; Task Force of the American College of Critical Care Medicine (ACCM) of the Society of Critical Care Medicine (SCCM), American Society of Health-System Pharmacists (ASHP), American College of Chest Physicians. Clinical practice guidelines for the sustained use of sedatives and analgesics in the critically ill adult. Crit Care Med. 2002;30(1):119-41.

11. CDC/NHSN surveillance definitions for specific types of infections. (Accessed Sept 5, 2016). Available from: http://www.cdc.gov/nhsn/pdfs/ pscmanual/17pscnosinfdef_current.pdf

12. Guiraoa X, Ariasa |, Badía |M, García-Rodríguez |A, Mensa |, Alvarez-Le rma $F$, et al. Recommendations in the empiric anti-infective agents of intra-abdominal infection. Cir Esp. 2010;87(2):63-81.

13. Dellinger RP, Levy MM, Rhodes A, Annane D, Gerlach H, Opal SM, et al; Surviving Sepsis Campaign Guidelines Committee including the Pediatric Subgroup. Surviving Sepsis Campaign: international guidelines for management of severe sepsis and septic shock 2012. Crit Care Med. 2013;41(2):580-637.

14. Sociedad Española de Medicina Intensiva Crítica y Unidades Coronarias, Grupo de Trabajo de Enfermedades Infecciosas y Sepsis. Estudio Nacional de Vigilancia de Infección Nosocomial en Servicios de Medicina Intensiva (ENVIN) 2015. (Accessed Sept 5, 2016). Available from: http:// www.semicyuc.org/sites/default/files/envin-uci_informe_2015. pdf
15. Olaechea PM, Insausti J, Blanco A, Luque P. Epidemiology and impact of nosocomial infections. Med Intensiva. 2010;34(4):256-67.

16. Kollef $M H$, Fraser V). Antibiotic resistance in the intensive care unit. Ann Intern Med. 2001;134(4):298-314

17. Warren DK, Liao RS, Merz LR, Eveland M, Dunne WM Jr. Detection of methicillin-resistant Staphylococcus aureus directly from nasal swab specimens by a real-time PCR assay. J Clin Microbiol. 2004;42(12):5578-81.

18. Amador JS, Carrasco JP, Morales AA, Cortes CP. Therapeutic evaluation of prolonged infusions of $\beta$-lactam antibiotics in the treatment and management of critically ill patients. J Pharm Pharmacogn Res. 2017;5(2):88-95.

19. Therre $H$. National policies for preventing antimicrobial resistance: the situation in 17 European countries in late 2000. Euro Surveill. 2001;6(1):5-14.

20. Feng P, Truant AL, Meissler JJ Jr, Gaughan JP, Adler MW, Eisenstein TK Morphine withdrawal lowers host defense to enteric bacteria: spontaneous sepsis and increased sensitivity to oral Salmonella enterica serovar Typhimurium infection. Infect Immun. 2006;74(9):5221-6.

21. Helmy SA, Al-Attiyah RJ. The immunomodulatory effects of prolonged intravenous infusion of propofol versus midazolam in critically ill surgical patients. Anaesthesia. 2001;56(1):4-8.

22. Cronin Al, Aucutt-Walter NM, Budinetz T, Bonafide CP, DiVittore NA Gordin $V$, et al. Low-dose remifentanil infusion does not impair natura killer cell function in healthy volunteers. Br | Anaesth. 2003;91(6):805-9.

23. Palomar M, Rodríguez $P$, Nieto $M$, Sancho S. Prevention of nosocomial infection in critical patients. Med Intensiva. 2010;34(8):523-33. 